\title{
Anatomy and Pathology of the Basal Ganglia
}

\author{
P.L. McGeer, E.G. McGeer, S. Itagaki and K. Mizukawa
}

\begin{abstract}
Neurotransmitters of the basal ganglia are of three types: I, amino acids; II, amines; and III, peptides. The amino acids generally act ionotropically while the amines and peptides generally act metabotropically. There are many examples of neurotransmitter coexistence in basal ganglia neurons. Diseases of the basal ganglia are characterized by selective neuronal degeneration. Lesions of the caudate, putamen, subthalamus and substantia nigra pars compacta occur, respectively, in chorea, dystonia, hemiballismus and parkinsonism. The differing signs and symptoms of these diseases constitute strong evidence of the functions of these various nuclei. Basal ganglia diseases can be of genetic origin, as in Huntington's chorea and Wilson's disease, of infectious origin as in Sydenham's chorea and postencephalitic parkinsonism, or of toxic origin as in MPTP poisoning. Regardless of the etiology, the pathogenesis is often regionally concentrated for reasons that are poorly understood. From studies on Parkinson and Huntington disease brains, evidence is presented that a common feature may be the expression of HLA-DR antigen on reactive microglia in the region where pathological neuronal dropout is occurring.
\end{abstract}

RÉSUMÉ: Anatomie et pathologie des noyaux gris centraux. Il y a trois types de neurotransmetteurs au niveau des noyaux gris centraux: 1) les acides aminés; 2) les amines; 3) les peptides. Les acide aminés agissent généralement par ionotropie alors que les amines et les peptides agissent généralement par métabotropie. Il existe plusieurs exemples de la coexistence de différents neurotransmetteurs dans les neurones de ces noyaux. Les maladies atteignant ces noyaux sont caractérisées par une dégénérescence neuronale sélective. Des lésions du caudé, du putamen, du sous-thalamus et de la pars compacta de la substance noire se retrouvent respectivement dans la chorée, la dystonie, l'hémiballisme et le parkinsonisme. Le fait que les signes et symptômes de ces maladies soient différents témoigne de la fonction de ces divers noyaux. Les maladies des noyaux gris centraux peuvent être d'origine génétique, comme dans la chorée de Huntington et la maladie de Wilson, d'origine infectieuse comme dans la chorée de Sydenham et le parkinsonisme post-encéphalitique, ou d'origine toxique comme dans l'empoisonnement par le MPTP. Quelle que soit l'étiologie, la pathogénèse est souvent concentrée dans une région, pour des raisons qui sont encore mal comprises. A partir d'études sur des cerveaux de patients atteints de maladie de Parkinson ou de Huntington, nous présentons des observations qui attestent qu'un élément commun à ces maladies est peut-être l'expression de l'antigène HLA-DR sur la microglie réactionnelle dans les régions où survient une perte neuronale pathologique.

Can. J. Neurol. Sci. 1987; 14:363-372

\section{A. Anatomical Considerations}

The basal ganglia are a collection of subcortical nuclei which process motor information in parallel with the cerebellum. They are here defined to consist of the caudate, putamen, external and internal segments of the globus pallidus, the subthalamic nucleus, and the pars compacta (SNC) and pars reticulata (SNR) of the substantia nigra. A simplified diagram showing the main anatomical arrangements of the basal ganglia is shown in Figure 1. The diagram is divided into input, processing, and output circuits. The input, shown in Figure 1a, is mainly from the massive corticostriatal glutamate tract with less significant tracts from midline thalamic and brainstem nuclei. Within the basal ganglia, the initial stage of data processing input data occurs in the caudate and putamen; information is then filtered through the external pallidum and subthalamic nucleus for output from the internal pallidum and SNR. The pathways are shown in Figure 1b. Output from the basal ganglia consists of GABA tracts mainly to the thalamus but also to the brainstem as shown in Figure 1c. The SNC provides a feedback loop to the caudate and putamen. These global arrangements provide for fast excitatory input from the cortex, extensive internal computation, and fast inhibitory output to the thalamus. The yield is mainly in the form of inhibitory information reaching the thalamus which is complementary in nature and contemporaneous in time to that processed by the lateral lobes of the cerebellum.

The basal ganglia also provide correlative activity for emotional and other nonmotor functions of brain. There are thus connections of a more subtle nature involving the brainstem, hypothalamus, nucleus accumbens, and other structures. The pathways of the basal ganglia themselves, along with these interconnecting pathways, involve a broad spectrum of neuro- 


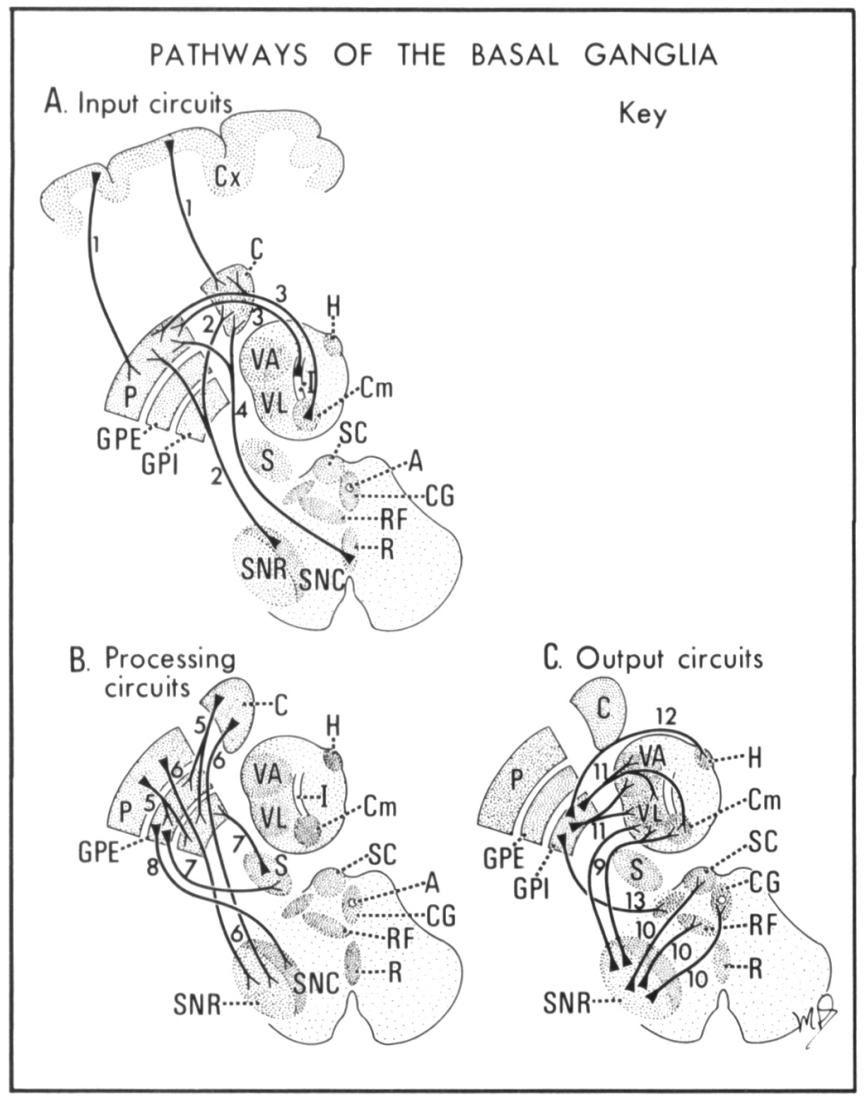

Figure I - Major pathways of the basal ganglia. A. Input circuits to the basal ganglia plus the nigro-striatal feedback loop. B. Processing circuits within the basal ganglia. C. Output circuits of the basal ganglia. (I) Corticostriatal, (2) Nigrostriatal, (3) Thalamo-striatal, (4) Raphestriatal, (5) Striatopallidal, (6) Striatonigral, (7) Pallidal-subthalamic-pallidal, (8) Pallidonigral, (9) Nigrothalamic, (10) Nigrobrainstem, (1I) Pallidothalamic, (12) Pallidohabenula, (13) Pallidotegmental. CX, cerebral cortex; $C$, caudate nucleus; $P$, putamen; $G P E$, external globus pallidus, $G P I$, internal globus pallidus; $S$, subthalamic nucleus; SNC, substantia nigra, pars compacta; SNR, substantia nigra, pars reticulata; $V L$, ventral lateral thalamic nucleus; VA, ventral anterior thalamic nucleus; $I$, intralaminar thalamic nucleus; $C M$, centrum medianum thalamus; $S C$, superior colliculus; $R F$, reticular formation; $C G$, central gray; $R$, raphe system; A, aqueduct of Sylvius.

transmitter types. As a result, the basal ganglia form one of the richest areas in brain for neurotransmitter investigation.

Neurotransmitters and their receptors can be divided into three broad categories. These are listed in Table 1. The categories of neurotransmitters are amino acids, amines and peptides. The categories of receptors are ionotropic, metabotropic and genotropic. The type 1 amino acid transmitters represented in the basal ganglia are glutamate (excitatory) and GABA (inhibitory). The type 2 amine transmitters are mainly acetylcholine and dopamine while there are many type 3 peptide transmitters.

The action of the neurotransmitters is determined by the nature of their postsynaptic receptors. Ionotropic receptors are those which open either excitatory or inhibitory ionic gates. The action is rapid $\left(10^{-3} \mathrm{sec}\right)$, point to point in specificity, and is accompanied by increased conductance in the postsynaptic membrane. Amino acid transmitters operate these gates. The gate which is opened in the case of glutamate is an excitatory $\mathrm{Na}^{+}$gate. The gate in the case of GABA is an inhibitory $\mathrm{Cl}^{-}$ gate. Metabotropic receptors do not open ionic gates but stimulate second messengers which are internal to the postsynaptic

\begin{tabular}{|c|c|c|}
\hline Transmitter Type & $\begin{array}{c}\text { Concentration Range } \\
\text { (nanomoles/gm tissue) }\end{array}$ & Major Receptor Type \\
\hline Amino acids & $2-14 \times 10^{3}$ & ionotropic \\
\hline Amines & $1-25$ & metabotropic \\
\hline Peptides & $10^{-3}-1$ & unknown \\
\hline Receptor Type & Locus of Action & $\begin{array}{c}\text { Typical Response } \\
\text { Time (sec) }\end{array}$ \\
\hline ionotropic & membrane ion channels & $10^{-3}$ \\
\hline metabotropic & $\begin{array}{l}\text { second messenger } \\
\text { systems }\end{array}$ & $10^{-1}$ \\
\hline genotropic & $\begin{array}{l}\text { transcription of specific } \\
\text { mRNA }\end{array}$ & $10^{3}-10^{6}$ \\
\hline
\end{tabular}

cell. The time course is slower (circa $10^{-1} \mathrm{sec}$ ), and the action initiated tends to be more general, i.e. a single amine neuron usually has an extensive number of branches to initiate a metabotropic response in many postsynaptic neurons. Ions do not traverse the membrane following receptor activation and therefore there is no conductance increase. Amines and peptides operate the metabotropic receptors which in turn activate the second messenger systems. An example is the stimulation of cAMP production by the dopamine $D_{1}$ receptor.

Little is yet known about receptors for genotropic transmission. Receptor action is translocated to the nucleus. RNA polymerase II activity then initiates transcription which results in increased specific messenger RNA appearing in the cytoplasm. Appropriate protein is then synthesized using the mRNA. The response time is much slower $\left(\mathrm{ca} 10^{3}-10^{6} \mathrm{sec}\right)$. So far steroid receptors in the basal ganglia and hypothalamus provide the best examples of genotropic transmission, but the emerging techniques of quantitative in situ hybridization to specific mRNA will make possible extensive investigation of this potentially rich field in the future. The principles of neurotransmitters and their receptors have recently been reviewed by us along with details of the anatomical and physiological interrelations of the basal ganglia with other motor structures of the brain. ${ }^{1-3}$

Greater detail concerning the transmitters in pathways of the basal ganglia are given in Table 2 ; they are too numerous to be presented in a single diagram. They are arranged according to transmitter type and include input and output, as well as the processing pathways. Since colocalization of transmitters can take place in the basal ganglia, there may be some redundancy in the pathways described. Much work remains to be done in defining the extent of colocalization in basal ganglia structures.

\section{B. Pathology of the Basal Ganglia}

Many different diseases affect the basal ganglia and it is beyond the scope of this brief review to do more than outline some of the common principles which seem to apply. Such diseases cover the etiological spectrum and include those of infectious, genetic and toxic origin. Many are of unknown cause, or are only superficially understood, so that pathological investigation of basal ganglia disease represents a formidable challenge for the future. An unexplained feature of many diseases of the basal ganglia is regional specificity. For example, Huntington's chorea, which is of genetic origin, particularly affects the caudate nucleus and, to a somewhat lesser extent, 


\section{LEGENDS TO FIGURES (pages 366 and 367)}

Figure 2 - Staining of SN neurons and microglia in: parkinsonism dementia (female, 76) $(A)$, Huntington's chorea $($ male, 70) $(B)$, and non-neurological control (male, 77) (C).A-I, B-I, C-I are anti-HLA-DR staining with a mouse monoclonal antibody. Notice in $A-1$ the swollen, reactive microglia (purple) in the vicinity of unstained melanin-containing dopamine neurons (brown). Immunohistochemical staining was with antibody kindly supplied by Dr.F.Takei of the University of B.C. It was derived from the HB-104 American cell culture line. Identical staining was obtained with commercial anti-HLA-DR monoclonal antibody (Becton-Dickinson, Mountain View, California). Immunohistochemical staining was by the method of Tago et al. ${ }^{46}$ using a nickel-ammonium sulfate intensification method. Notice melanin granules within the HLA-DR-positive phagocytosing microglia in A-l as well as some extracellular melanin. The $H$ untington's disease case $(B-1)$ showed no evidence of degenerating melanin-containing neurons but some HLA-DR-positive reactive microglia were present. The normal case showed no HLA.DR positive reactive microglia $(C-1) .[A-2, B \cdot 2, C-2]$ : Immunohistochemical staining of similar areas of the $S N C$ with a rabbit polyclonal tyrosine hydroxylase (TH) antibody (Eugene Tech. Int., N.J.) The Tago intensification method ${ }^{46}$ was employed so that TH-positive neurons and their processes appear purple. Brown melanin granules are unstained. Notice the few TH-positive staining cell bodies, often without processes in A-2. Also notice the existence of many separated and swollen fibers, apparently in various stages of degeneration. The Huntington's case (B-2) showed healthy TH staining of neurons and their processes with no evidence of swelling or degeneration. The same applied to the normal case $(C-2)$. Double immunohistochemical staining for HLA-DR and substance $P$ in the SN in the Huntington's case is shown in B-3 and B-4. Immunohistochemical staining for HLA-DR was carried out as in B-I. The section was then treated with a mouse monoclonal anti-rat substance $P$ antibody (Sera-lab, Sussex, England), followed by the Vector ABC second antibody system (Vector Laboratories, Burlingame, Cal.) which produces a brown reaction product. HLA-DR microglia are purple, substance $P$ fibers are light brown and melanin-containing dopaminergic perikarya are unstained and dark brown. Notice the small HLA-DR-positive reactive microglia in the vicinity of the brown substance $P$ processes in B-4 (SNR). B-3 shows double staining for HLA-DR and substance $P$ in the SNC. Again, notice the HLA-DR-positive microglia in the vicinity of substance $P$ nerve processes but apparently not phagocytosing melanin-containing dopamine cells.

Figure $3-H L A-D R$ staining in the caudate nucleus of parkinsonism dementia (A), Huntington's chorea (B), and control (C). HLA-DR staining as in Figure 2 . In (A) notice the presence of only a few HLA-DR-positive microglia. Presumbly, these are involved in the' phagocytosis of dopaminergic nerve endings. Notice the much more plentiful existence of reactive microglia in the Huntington's case (B) where neuronal degeneration is taking place and the lack of HLA-DR-positive cells in the control $(C)$.

Figure 4-Immunohistochemical staining of the SNC in the case of parkinsonism-dementia with anti-leu M3 antibody. The mouse monoclonal antibody (Becton-Dickinson) is active against human monocytes from which the antigen was derived. Method of Tago ${ }^{46}$ was employed.

Figure 5 -Immunohistochemical staining of the SNC in parkinsonism-dementia with mouse-monoclonal anti-IL2-receptor (Becton-Dickinson). The method of Tago ${ }^{46}$ was used as in the previous figures. Notice the positive staining of a reactive microglial cell near a degenerating melanin-containing dopaminergic neuron.

Bar $=50$ microns. Magnification identical in all photomicrographs. 


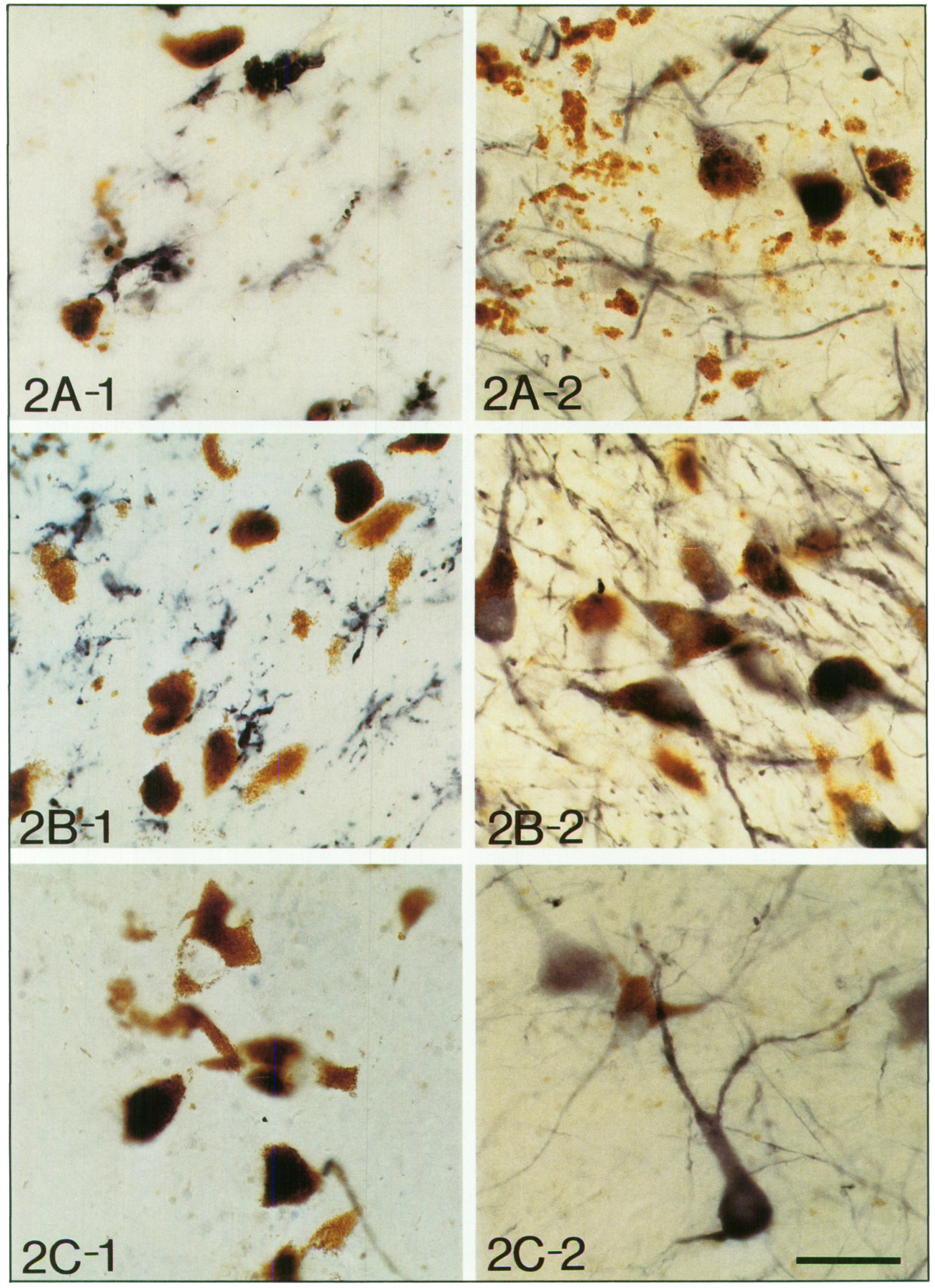




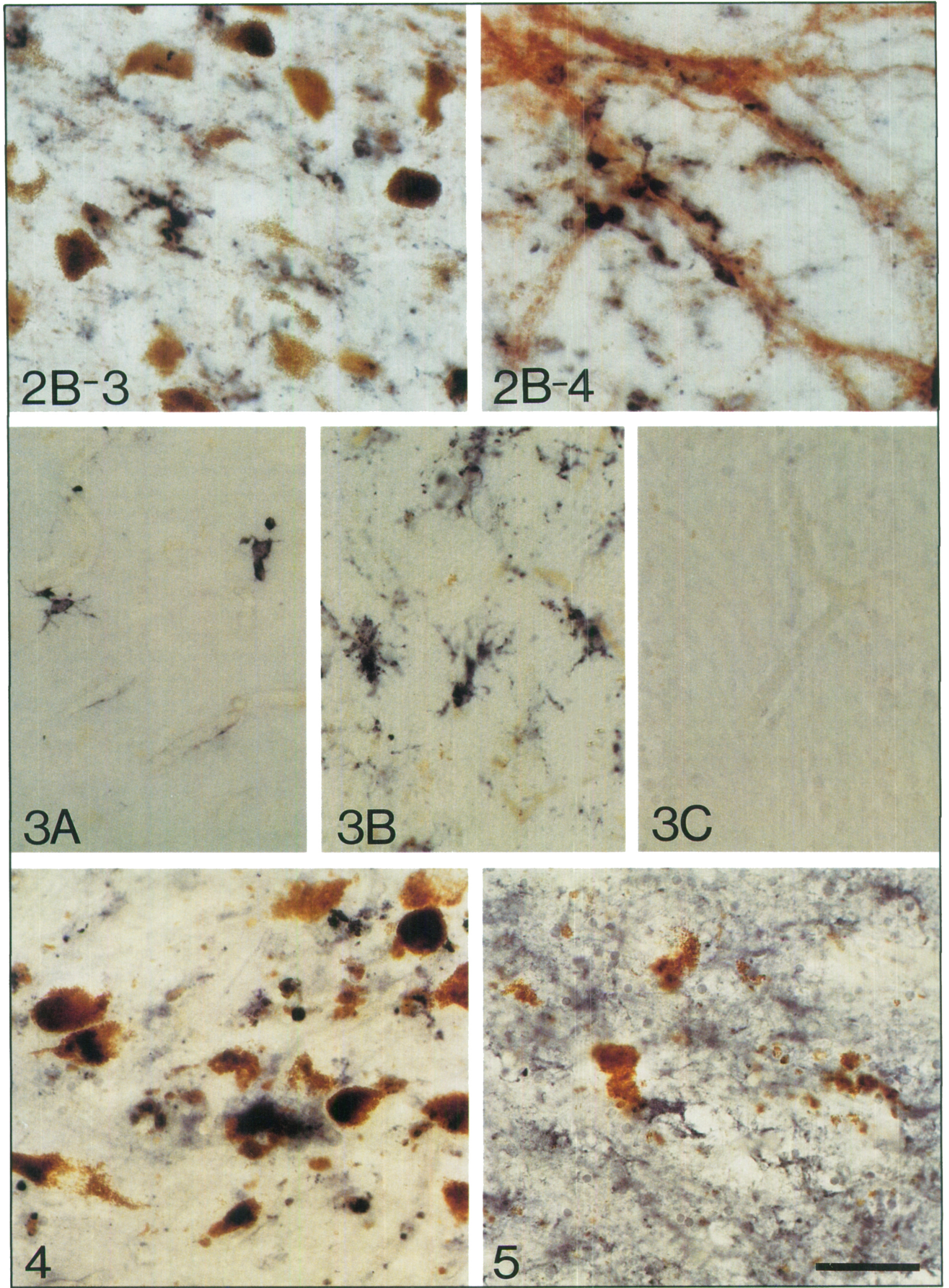


Table 2: Transmitters in the Basal Ganglia and the Paths They Serve'

\begin{tabular}{ll}
\hline \hline & $\begin{array}{l}\text { Interneurons [ ] or } \\
\text { Pransmitter }\end{array}$ \\
\hline
\end{tabular}

Type I

Glutamate/Aspartate ${ }^{2}$

Cortex to CP, SN

Subthalamus to GP, SN

Tegmentum to $\mathrm{SN}$

GABA

[CP], CP to GP, SN, EP

GP to EP, CP, SN, (subthalamus)

EP to thalamus, tegmentum, habenula Raphe to CP

NAc to GP, (SN)

$\mathrm{SN}$ to $\mathrm{CP}$, thalamus, SuC, tegmentum, midbrain

(Cortex to $\mathrm{SN}$ )

Type II

Acetylcholine

[CP], VnGP to CP

$\mathrm{GP}$ to $\mathrm{CP}$

Tegmentum to SN

Noradrenaline

$\mathrm{LC}$ to $\mathrm{CP}, \mathrm{SN}$

Adrenaline

LC to $C P,(S N)$

Dopamine

SN to CP, GP, spinal cord, amygdala, olfactory system, subthalamus

Raphe to CP

Serotonin

Raphe to CP, SN

Histamine

Hypothalamus to $\mathrm{CP}$

\section{Type III}

Dynorphin

Enkephalin

Tachykinins (SP and SK)

Cholecystokinin

\section{Somatostatin}

Oxytocin

Vasopressin

Neuropeptide Y

CP to GP, SN, EP

CP to GP, EP, SN

CP to GP, SN, EP, VnGP

Cortex to $\mathrm{CP}$

Amygdala to $\mathrm{CP}$

Contra. SN to CP

(NST to SN)

([CP] or CP to ?)

[CP], (Amygdala to CP)

EP to habenula

Hypothalamus to $\mathrm{SN}$

(Hypothalamus to SN)

IB-236

[CP]

Neurotensin

(CP or CP to ?)

[CP] and CP to SN

${ }^{1}$ Based on previous reviews (McGeer et al. 1984; McGeer and McGeer 1987 ) in which the references are given. Where there is some but not definitive evidence, the pathway is in parentheses. Abbreviations: Contra., contralateral; CP, caudate/putamen; EP, entopeduncular nucleus; GP, globus pallidus; LC, locus coeruleus and subcoeruleus; NAc, nucleus accumbens; NST, nucleus tractus solitarius; SK, substance K; SN, substantia nigra; SP, substance P; SuC, superior colliculus; VnGP, ventral globus pallidus, medial basal forebrain; VTA, ventral tegmental area

${ }^{2}$ Most of the paths described probably use glutamate as the only or main excitatory amino acid

the putamen. The globus pallidus is less involved and the cortex only mildly involved. Why all neuronal types in the caudate nucleus should be attacked in a disease of genetic origin is unclear. The same applies to some extent in Parkinson's disease where dopamine cells of the SNC are primarily involved whereas dopamine cells of other areas, as well as serotonergic and noradrenergic cells, are less involved.

Whatever the reasons may be, this regional proclivity of disease has provided a great deal of information about the physiological functions of many nuclei within the basal ganglia. In fact, human pathological conditions have provided the most decisive information to date on such functioning.

Table 3 summarizes some of this information by disease. The table gives the probable cause of the disease, the region within the basal ganglia most affected and the prominent signs that clinicians use for diagnostic purposes. Sydenham's chorea often appears in young people following group $A B$-hemolytic streptococcal infection. Antibodies are produced which cross-react with neurons, especially in the caudate and putamen, producing chorea. ${ }^{4}$ The choreiform neurological signs are remarkably comparable to those in Huntington's disease. Somewhat different signs are observed in Wilson's disease, a genetic defect involving a loss of the copper transporting protein, ceruloplasmin. Excess copper is deposited in the lentiform nucleus, amongst other organs, resulting in preferential degeneration of putamenal neurons. ${ }^{5}$ A flapping tremor accompanied by rigidity results. Isolated cases of dystonia, i.e. athetoid movements accompanied by increased muscle tone, have been shown to result from vascular lesions which selectively destroy putamenal neurons, particularly in the lateral aspect. ${ }^{6}$ These results indicate that loss of caudate neurons results in choreiform movements which develop rigid, dystonic features as the putamen becomes involved. Vascular lesions to the subthalamic nucleus produce an extreme form of these motor abnormalities called ballismus. Usually, this is a unilateral occurrence producing hemiballismus. ${ }^{5}$

Lesions to the SNC produce the parkinsonian syndrome. They may be postencephalitic, i.e. of infectious origin, toxic, as in MPTP poisoning, ${ }^{7}$ or of unknown origin, as in idiopathic parkinsonism.

Table 4 summarizes some of the neurotransmitter marker changes observed in selected basal ganglia disorders. In many cases, the changes reflect losses of neurons and their processes. In others, the changes may be functional ones related to compensatory down regulation. The most extensive changes that have been measured are those involving Huntington's disease where a pan-neuronal loss occurs in the caudate and, to a lesser extent, the putamen. There are also significant neuronal losses in the globus pallidus, but in the SN cell bodies seem to be spared with only terminals of degenerating neostriatal neurons being affected. Some cortical loss also occurs in Huntington's disease and therefore it is not surprising that glutamate uptake, an index of corticostriatal glutamate nerve endings, should be decreased in the caudate and putamen. All GABA and acetylcholine indices are decreased because the caudate and putamen contain these types of neurons. Dopamine and homovanillic acid are normal because $\mathrm{SN}$ dopaminergic neurons are spared. CCK, dynorphin, enkephalin and substance $P$ are all decreased, again because of the existence of intrinsic neurons of these types in the neostriatum and globus pallidus. In Parkinson's disease, it is indices of dopaminergic, and to a lesser extent serotonergic and noradrenergic neurons that are affected. Some decreases have also been reported for enkephalin and substance $P$ indices. 
Table 3: Regional Effects of Basal Ganglia Disease

\begin{tabular}{|c|c|c|c|}
\hline Disease & Causation & $\begin{array}{l}\text { Basal Ganglia Area } \\
\text { Most Affected }\end{array}$ & Most Prominent Signs \\
\hline Huntington's Chorea & Genetic & Caudate \& putamen & Chorea \\
\hline Hemiballismus & Vascular accident & Subthalamic nucleus & Hemiballism \\
\hline $\begin{array}{l}\text { Parkinson's disease } \\
\text { Idiopathic } \\
\text { Postencephalitic }\end{array}$ & $\begin{array}{l}\text { Unknown } \\
\text { Infection }\end{array}$ & $\begin{array}{l}\text { SNC } \\
\text { SNC }\end{array}$ & $\begin{array}{l}\text { Akinetic rigidity } \\
\text { Akinetic rigidity }\end{array}$ \\
\hline
\end{tabular}

The list in Table 4 is far from complete, and much study remains to be done on changes in individual nuclei of the basal ganglia in numerous disorders not reported in the table.

\section{Basal Ganglia Disease and the Immune System}

There are many mysteries concerning the immune system of the brain. There is no lymphatic drainage per se, and the blood/brain barrier restricts the entry of antibodies. Thus, the rules of the peripheral immune system do not automatically apply to brain. As one example, broad cross species transplantation is possible in brain under circumstances that would produce a vigorous host versus graft disease in the periphery. Human spinal cord neurons, ${ }^{8}$ sympathetic ganglia neurons, ${ }^{9}$ and adrenal medullary neurons ${ }^{10}$ have all been shown to survive in rat brain and even to produce physiological benefit. Survival of cross-species transplants is usually attributed to prevention of donor histocompatibility antigens from being presented to the host immune system. On the other hand, experimental allergic encephalomyelitis results if the host is exposed to its own nervous system tissue. ${ }^{11}$ On this and other grounds, it is believed that multiple sclerosis may be an autoimmune disorder.

In at least two diseases of the basal ganglia - Sydenham's chorea and Huntington's chorea - there have been multiple reports of circulating antibodies directed against host brain tissue. Husby et al. ${ }^{4}$ reported that the antineuronal antibody, which developed after a group A B-hemolytic streptococcal infection could be completely absorbed out by purified membranes from group A streptococci. About half the patients examined in a large group with well-documented Huntington's disease also demonstrated serum antineuronal antibodies, but these antibodies were not absorbed out by group A streptococcal membranes. ${ }^{12}$ Similar antibodies were detected in 6 out of 20 spouses of the Huntington's cases. A possible interpretation suggested was that the antineuronal antibodies might result from infection by a relatively common neurotropic virus but only those with genes for a susceptible immune response would suffer neuronal degeneration. Antineuronal antibodies were also detected in 11 of 33 parkinsonian cases that were studied. ${ }^{12}$

These previous studies may have some bearing on our recent finding that phagocytosing microglia in Parkinson's disease, Huntington's chorea and Alzheimer's disease all express the class II histocompatibility surface antigen HLA-DR. In the periphery, this surface antigen is expressed on most B-lymphocytes, certain T-lymphocytes, some macrophages and on a very restricted number of tissue cells. An important purpose of this surface antigen is to signal $T$-helper cells that a foreign antigen is being presented. T-helper cells recognize foreign antigen only when simultaneously presented with HLA-DR. The T-helper cells in turn stimulate the production of specific cytotoxic T-cells, as well as B-lymphocytes, which clone cells producing antibody against the antigen. These cells, however, do not attack the cells expressing HLA-DR. Instead, they attack cells expressing the same foreign antigen when appearing in combination with class I histocompatibility antigens. ${ }^{13}$

Microglia are normally present in minor concentration in brain. In pathological conditions, microglia become much more numerous and assume differing morphology. Their processes become shortened and swollen, and the perikaryon can assume a rod-shape or fat granular appearance. ${ }^{14}$ They can frequently be seen digesting neuronal elements. The origin of microglia is still uncertain. The classical work of del Rio Hortega suggested they were of mesodermal origin, migrating at an early developmental stage into brain tissue. More recent work has suggested that they are transformed monocytes which migrate from blood into brain tissue at the time when phagocytotic activity is required. $^{15}$

Figure 2 is a series of photomicrographs illustrating the relationship between reactive microglia which are HLA-DR positive and neuronal elements in parkinsonism dementia (Fig. 2A-1), Huntington's chorea (Fig. 2B-1) and control (Fig. 2C-1) $\mathrm{SN}$. In both Parkinson's disease and Huntington's chorea phagocytosing microglia expressing HLA-DR antigen can be seen. By contrast, no HLA-DR positive microglia can be observed in the control. Dopaminergic cell bodies in the SNC are revealed in the figures by the presence of melanin granules. Separate photomicrographs show dopaminergic cell bodies and their processes and substance $P$ terminals stained by immunohistochemical methods. In the parkinsonian, degenerating tyrosine hydroxylase (TH)-containing neuronal perikarya and processes can be seen (Fig. 2A-2). In Huntington's chorea, these elements are healthy (Fig. 2B-2), but substance P-positive nerve endings can be seen next to HLA-DR-positive reactive microglia in double immunostained specimens (Figs. 2B-3 and 2B-4).

The caudate nucleus also has reactive HLA-DR-positive microglia in Huntington's and Parkinson's disease but not in 
Table 4: Representative Postmortem Data on Some Neurotransmitters and Related Binding Sites in Basal Ganglia Nuclei in Huntington's Disease, Parkinson's Disease and Miscellaneous Movement Disorders ${ }^{\mathbf{a}}$

\begin{tabular}{|c|c|c|c|}
\hline Disease, Index (Ref) ${ }^{b}$ & $\mathbf{C P}$ & GP & SN \\
\hline 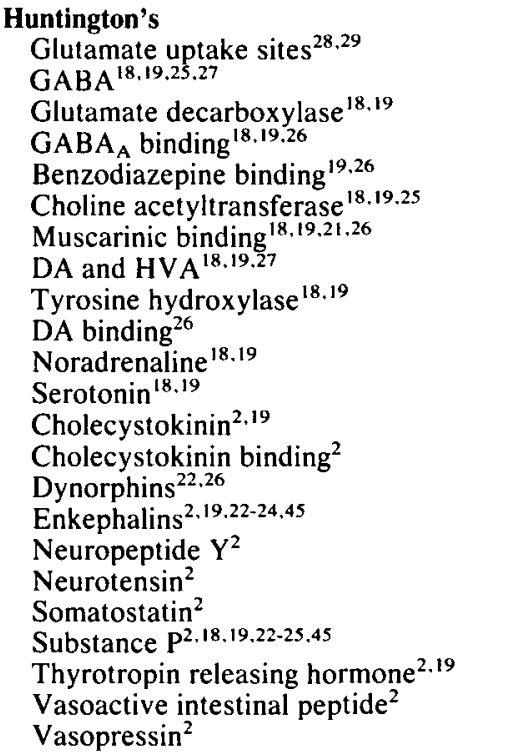 & $\begin{array}{l}\text { D } \\
\text { D } \\
D \\
D \\
D \\
D \\
D \\
\text { N } \\
\text { N/I } \\
\text { D } \\
\text { N } \\
\text { N } \\
\text { N } \\
D \\
D \\
\text { N/D-D } \\
\text { I } \\
\text { I/N } \\
I^{c} \\
D \\
\text { I } \\
\text { N }\end{array}$ & $\begin{array}{l}\mathrm{D} \\
\mathrm{D} \\
\mathrm{I} \\
\mathrm{N} \\
\mathrm{D} \\
\mathrm{D} / \mathrm{N}\end{array}$ & $\begin{array}{l}\text { D } \\
\text { D } \\
\text { D } \\
\text { D }\end{array}$ \\
\hline 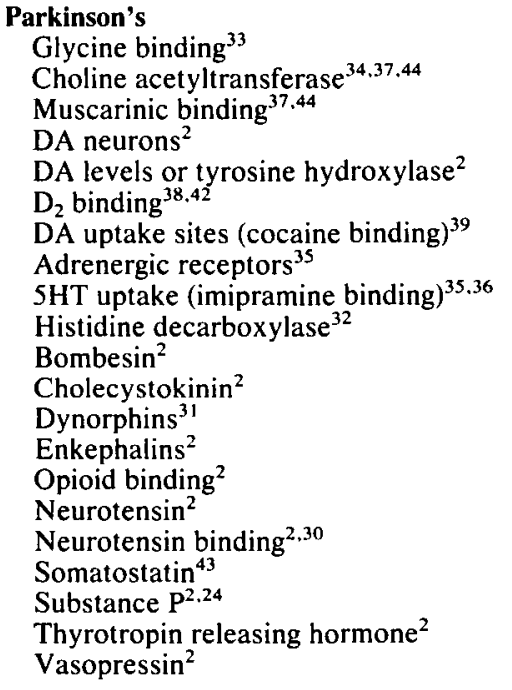 & $\begin{array}{l}\frac{N}{N}-\bar{N} / D \\
D \\
D \\
I d / N \\
D \\
D \\
D \\
N \\
D-N \\
N \\
N \\
N / D \\
D-N \\
N \\
\\
N \\
N \\
N\end{array}$ & $\begin{array}{l}\mathrm{D} \\
\mathrm{N} \\
\mathrm{N} \\
\mathrm{D} / \mathrm{N} \\
\mathrm{N}\end{array}$ & $\begin{array}{l}N \\
N \\
D \\
\\
D \\
D \\
N \\
D \\
D / N \\
N \\
N\end{array}$ \\
\hline $\begin{array}{l}\text { Dentato-rubro-pallido-luysian atrophy } \\
\text { GABA } \\
\text { Choline acetyltransferase } \\
\text { Substance } \mathrm{P}^{25}\end{array}$ & $\begin{array}{l}\mathrm{D} \\
\mathrm{D} \\
\mathrm{D}\end{array}$ & $\begin{array}{l}\mathrm{D} \\
\mathrm{D} \\
\mathrm{D}\end{array}$ & $\begin{array}{l}\mathrm{D} \\
\mathrm{D}\end{array}$ \\
\hline $\begin{array}{l}\text { Wilson's disease } \\
\text { Noradrenaline }^{41} \\
\text { Dopamine }^{41}\end{array}$ & $\begin{array}{l}\text { I } \\
\text { D }\end{array}$ & & \\
\hline $\begin{array}{l}\text { Striatopallidal infarction } \\
\text { Enkephalins }{ }^{40} \\
\text { Substance } \mathrm{P}^{40}\end{array}$ & & & $\begin{array}{l}\mathrm{D} \\
\mathrm{D}\end{array}$ \\
\hline
\end{tabular}

a $\mathrm{N}$ indicates no change, $\mathrm{D}$ a decrease and $\mathrm{I}$ an increase compared to normal controls; $N-D$ indicates different results in subnuclei and N/D or N/I indicates discrepant reports with the underlined letter being the more generally reported finding. CP, caudate/putamen; GP, globus pallidus; SN, substantia nigra.

'Many of the references to changes in Huntington's disease or to dopamine and peptide changes are in previous reviews ${ }^{2,18,19}$; only references not cited there are given here.

${ }^{c}$ Marshall et $\mathrm{al}^{45}$ report a loss of SOM cells in CP but an increase in density of SOM-positive fibers, with little or no change in fiber staining in GP or SN.

'In untreated; normal in dopa-treated cases. ${ }^{20}$

e Single case but large abnormalities normals (Figure 3). This is consistent with the loss in Huntington's disease of caudate neurons, some of which are substance $P$ neurons (Table 4) that project to the SN (Table 2), and the loss in Parkinson's disease of caudate nerve endings. Evidence that some reactive microglia may be of monocytic origin is shown in Figure 4. This photomicrograph of the parkinsonian SN illustrates positive immunohistochemical staining of reactive microglia for leu-M3 antigen. ${ }^{16}$

Evidence that reactive microglia may be signaling to the peripheral T-cell mediated immune system is indicated by the presence of interleukin-2 (IL-2) receptors ${ }^{17}$ on SN microglia in the Parkinson's disease case (Figure 5). IL-2 is thought to be produced only by T-lymphocytes. It stimulates the expression of HLA-DR antigen and other components of the peripheral immune system. The presence of IL-2 receptor, revealed in Figure 5 by positive staining with anti-IL- 2 receptor antibody, suggests signaling by the microglia for IL-2.

It is as yet difficult to interpret these data because much less is known about the arrangements for brain immune defenses than is known about the periphery. T-lymphocytes and monocytes were not observed in our specimens, making it difficult to draw the kind of conclusions that would be possible for peripheral autoimmune or other disorders. It is not yet known whether the expression of HLA-DR positive antigen on the surface of microglia appears whenever there is an injury to brain tissue regardless of cause. Even if the etiological agent differed, as is clearly the case in Huntington's chorea and Parkinson's disease, it is still possible that a neuronal antigen presented to a naive peripheral immune system could generate an autoimmune response in susceptible individuals. A requirement would be the participation of $\mathrm{T}$-helper cells and other elements of the T-lymphocyte series. This possibility deserves closer investigation in the future.

\section{SUMMARY}

The basal ganglia contain a wide variety of neuronal types. Prominent systems are the fast excitatory glutamate input to the neostriatum and the fast GABA inhibitory output from the internal pallidum and SNR. Processing neurons within the basal ganglia include GABA, acetylcholine, dynorphin, enkephalin, substance $P$, cholecystokinin, calcitonin-gene-related peptide, somatostatin, neuropeptide $\mathrm{Y}$, neurotensin and some other peptidergic neurons. Dopamine neurons form a feedback loop from the SNC to the neostriatum while serotonin, noradrenaline, adrenaline, histamine, oxytoxin and vasopressin all provide input to the basal ganglia. Diseases of the basal ganglia tend to be regionally specific and therefore much information regarding the particular function of individual nuclei has come from a study of these diseases. Pathological lesions of the caudate and putamen tend to produce chorea; the putamen dystonia; the subthalamic nucleus hemiballismus; and the SNC akinetic rigidity. Autoimmune phenomena have been suggested by reports of antineuronal antibodies in Sydenham's chorea, Huntington's chorea and Parkinson's disease. We report here the presence of HLA-DR antibodies on phagocy tosing microglia in the SN and caudate nucleus of cases of Parkinsonism dementia and Huntington's chorea. In the case of Parkinson's disease, phagocytosis involves dopamine cells of the SN and their processes in the caudate nucleus. In the case of Huntington's chorea, such dopaminergic elements are relatively spared but phagocy- 
tosis of nerve endings in the $\mathrm{SN}$, some of which are substance $\mathrm{P}$-containing, is evident. Monocytic origin of some reactive microglia is suggested by positive anti-leu-M3 immunohistochemical staining. Interrelationships with the T-cell mediated immune system is indicated by positive staining for IL-2 receptors on the membranes of some reactive microglia.

\section{ACKNOWLEDGEMENTS}

The authors wish to thank Mrs. Joanne Suzuki for skillful technical assistance. This research was supported by grant $5-90033$ from the Medical Research Council of Canada and by the Alzheimer's Association of British Columbia.

\section{REFERENCES}

1. McGeer EG, Staines WA, McGeer PL. Neurotransmitters in the basal ganglia. Can J Neurol Sci 1984; 11: 89-99.

2. McGeer PL, Eccles JC, McGeer EG, eds. Molecular Biology of the Mammalian Brain. 2nd ed. New York: Plenum Press, 1987.

3. McGeer EG, McGeer PL. Biochemical neuroanatomy of the basal ganglia. In: Calne DB, ed. Drugs for the Treatment of Parkinson's Disease. Berlin: Springer-Verlag (in press)

4. Husby G, van de Rijn I, Zabriskie JB, et al. Antineuronal antibody in Sydenham's chorea. Lancet 1977; i: 1208.

5. Brain Lord, Walton JN, eds. Brain's Diseases of the Nervous System. 9th ed. London: Oxford University Press, 1985.

6. Burton K, Farrell K, Li D, et al. Lesions of the putamen and dystonia: CT and magnetic resonance imaging. Neurol 1984; 34 : 962-965

7. Burns RS, Chiueh CC, Markey SP, et al. A primate model of parkinsonism: selective destruction of dopaminergic neurons in the pars compacta of the substantia nigra by $\mathrm{N}$-methyl-4-phenyl1,2,3,6-tetrahydropyridine. Proc Natl Acad Sci USA 1983; 80: 4546-4550.

8. Kamo H, Kim SU, McGeer PL, et al. Transplantation of cultured human spinal cord cells into the rat motor cortex: use of phaseolus vulgaris leucoagglutinin as a cell marker. Neurosci Lett 1987; 76: 163-167.

9. Kamo H, Kim SU, McGeer PL, et al. Functional recovery in a rat model of Parkinson's disease following transplantation of cultured human sympathetic neurons. Brain Res 1986; 397: 372-376.

10. Kamo H, Kim SU, McGeer PL, et al. Transplantation of cultured fetal human adrenal chromaffin cells to rat brain. Neurosci Lett 1985; 57: 43-48.

11. Kabat EA, Wolf A, Bezer AE. The rapid production of acute disseminated encephalomyelitis in rhesus monkeys by injection of heterologous and homologous brain tissue with adjuvants. $J$ Exp Med 1947; 85: 117.

12. Husby G, Wedege E, Williams RC Jr. Characterization of brain proteins reacting in vitro with anti-neuronal antibodies in patients with Huntington's disease. Clin Immunol Immunopath 1978; 11 : 131-141.

13. Tonegawa $S$. The molecules of the immune system. Scientific Amer 1985; 122-131.

14. Penfield $W$. Microglia and the process of phagocytosis in gliomas. Am J Pathol 1925; 1: 77-89.

15. Polak M, DiAmelio F, Johnson JE Jr, et al. Microglial cells origins and reactions. In: Haymaker W, Adams RD, eds. Histology and Histopathology of the Nervous System. Springfield: Charles C Thomas, 1982; 481-559.

16. Dimitriu-Bona A, Burmester GR, Waters SJ, et al. Human mononuclear phagocyte differentiation antigens. I. Patterns of antigenic expression on the surface of human monocytes and macrophages defined by monoclonal antibodies. J Immunol 1983; 130 145-152.

17. Urdal DL, March CJ, Gillis S, et al. Purification and chemical characterization of the receptor for interleukin 2 from activated human lymphocytes and from a human T-cell lymphoma cell line. Proc Natl Acad Sci USA 1984; 81: 6481-6485.
18. Coyle JT, McGeer EG, McGeer PL, et al. Neostriatal injections: a model for Huntington's chorea. In: McGeer EG, Olney JW, McGeer PL, eds. Kainic Acid as a Tool in Neurobiology. New York: Raven Press, 1978; 139-159.

19. McGeer PL, McGeer EG. Excitotoxic amino acids as tools in neurobiology. Rev Pure Appl Pharmacol Sci 1983; 4: 213-270.

20. Guttman M, Seeman P, Reynolds GP, et al. Dopamine $D_{2}$ receptor density remains constant in treated Parkinson's disease. Ann Neurol 1986; 19: 487-492.

21. Penney JB Jr, Young AB. Quantitative autoradiography of neurotransmitter receptors in Huntington's disease. Neurol 1982; 32: 1391-1395.

22. Seizinger BR, Liebisch DC, Kish SJ, et al. Opioid peptides in Huntington's disease: alterations in prodynorphin and proenkephalin system. Brain Res 1986; 378: 405-408.

23. Ferrante R, Kowall N, Richardson E Jr, et al. Topography of enkephalin, substance $P$ and acetylcholinesterase staining in Huntington's disease striatum. Neurosci Lett 1986; 71: 283-288.

24. Zech M, Bogerts B. Methionine-enkephalin and substance $P$ in the basal ganglia of normals, Parkinson patients, Huntington patients, and schizophrenics. Acta Neuropathol 1985; 68: 32-38.

25. Kanazawa I, Sasaki H, Muramoto O, et al. Studies on neurotransmitter markers and striatal neuronal cell density in Huntington's disease and dentatorubropallidoluysian atrophy. J Neurol Sci 1985; 70: 151-165.

26. Whitehouse PJ, Trifiletti RR, Jones BE, et al. Neurotransmitter receptor alterations in Huntington's disease: autoradiographic and homogenate studies with special reference to benzodiazepine receptor complexes. Ann Neurol 1985; 18: 202-210.

27. Reynolds GP, Garrett NJ. Striatal dopamine and homovanillic acid in Huntington's disease. J Neural Transm 1986; 151-155.

28. Cross AJ, Slater P, Reynolds GP. Reduced high-affinity glutamate uptake sites in the brains of patients with Huntington's disease. Neurosci Lett 1986; 67: 198-202.

29. Greenamyre JT, Penney JB, Young AB, et al. Alterations in L-glutamate binding in Alzheimer's and Huntington's diseases. Science 1985; 227: 1496-1499.

30. Sadoul JL, Checler F, Kitabgi P, et al. Loss of high affinity neurotensin receptors in substantia nigra from parkinsonian subjects. Biochem Biophys Res Commun 1984; 125: 395-404.

31. Taquet H, Javoy-Agid F, Cesselin F, et al. Microtopography of methionine-enkephalin, dopamine and noradrenaline in the ventral mesencephalon of human control and parkinsonian brains. Brain Res 1982; 235: 303-314.

32. Garbarg M, Javoy-Agid F, Schwartz JC, et al. Brain histidine decarboxylase activity in Parkinson's disease. Lancet 1983i; 74-75.

33. deMontis $\mathbf{G}$, Beaumont $\mathbf{K}$, Javoy-Agid F, et al. Glycine receptors in the human substantia nigra as defined by $\left[{ }^{3} \mathrm{H}\right]$ strychnine binding. J Neurochem 1982; 38: 718-724.

34. Gaspar P, Javoy-Agid F, Plaska A, et al. Regional distribution of neurotransmitter synthesizing enzymes in the basal ganglia of human brain. J Neurochem 1980; 34: 278-283.

35. Cash R, Lasbennes F, Sercombe R, et al. Adrenergic receptors on cerebral microvessels in control and parkinsonian subjects. Life Sci 1985; 12: 531-536.

36. Raisman R, Cash R and Agid Y. Parkinson's disease: decreased density of ${ }^{3} \mathrm{H}$-imipramine and ${ }^{3} \mathrm{H}$-paroxetine binding sites in putamen. Neurol 1986; 36: 556-560.

37. Reisine TD, Fields JZ, Yamamura HI, et al. Neurotransmitter receptor alterations in Parkinson's disease. Life Sci 1977; 21: 335-344.

38. Guttman M, Seeman J. L-DOPA reverses the elevated density of D-2 dopamine receptors in Parkinson's diseased striatum. J Neural Transm 1986; 64: 93-103.

39. Schoemaker H, Pimoule C, Arbilla $S$, et al. Sodium dependent $\left[{ }^{3} \mathrm{H}\right]$ cocaine binding associated with dopamine uptake sites in the rat striatum and human putamen decrease after dopaminergic denervation and in Parkinson's disease. Naunyn-Schmiedeberg's Arch Pharmacol 1985; 329: 227-235.

40. Pioro EPJ, Hughes JT, Cuello AC. Loss of substance $P$ and enkephalin immunoreactivity in the human substantia nigra after striatopallidal infarction. Brain Res 1984; 292: 339-347. 
41. Nyberg P, Gottfries CG, Holmgren G, et al. Advanced catecholaminergic disturbances in the brain in a case of Wilson's disease. Acta Neurol Scandinav 1982; 65: 71-75.

42. Bokobza B, Rubert M, Scatton B, et al. $\left[{ }^{3} \mathrm{H}\right]$ Spiperone binding, dopamine and HVA concentrations in Parkinson's disease and supranuclear palsy. Eur J Pharm 1984; 99: 167-175.

43. Beal M, Mazurek M, Martin J. Somatostatin immunoreactivity is reduced in Parkinson's disease dementia with Alzheimer's changes. Brain Res 1986; 397: 386-388.
44. Ruberg M, Ploska A, Javoy-Agid, F et al. Muscarinic binding and choline acetyltransferase activity in parkinsonian subjects with reference to dementia. Brain Res 1982; 232: 129-139.

45. Marshall PE, Landis DMD, Zalneraitis EL. Immunocytochemical studies of substance $P$ and leucine-enkephalin in Huntington's disease. Brain Res 1983; 289: 11-26.

46. Tago H, McGeer PL, Bruce G, et al. Distribution of choline acetyltransferase-containing neurons of the hypothalamus. Brain Res 1987 (in press). 